\title{
Cist behind the Binns: the excavation of an Iron Age cist burial at the House of the Binns, West Lothian*
}

\author{
Daniel Rhodes ${ }^{1}$ and Elizabeth Jones ${ }^{2}$ \\ with contributions by Laura Sinfield ${ }^{3}$, Dawn McLaren ${ }^{4}$ and \\ Penelope Walton Rogers ${ }^{5}$
}

\begin{abstract}
During a routine archaeological monitoring visit to the National Trust for Scotland (NTS) property at the House of the Binns in August 2013, human bone was discovered eroding from a small bedrock quarry face. Following investigation by the NTS Archaeology Team this was identified as the remains of two male skeletons from the first centuries BC/AD. Both were buried within a single stone cist, with the remains of one individual (30-50 years old) clearly disturbed during the placement of the second (a young adult). The second individual was placed in a crouched position on his left side and was wearing a penannular brooch on his left shoulder. A significant element of the site is the survival of some extremely rare Iron Age textile upon the brooch.
\end{abstract}

\section{INTRODUCTION}

The House of the Binns is a 17th-century laird's house near Linlithgow and has been the home of the Dalyell family for 400 years. As with much of the National Trust for Scotland (NTS) estate, the wider property contains archaeological remains pre-dating the establishment of the house and surrounding parkland. The present house was built in 1612 by Thomas Dalyell, an Edinburgh merchant who had made his fortune at the court of King James VI and I in London. The Dalyell family gifted the house, its contents and the surrounding parkland, along with an endowment, to the NTS in 1944 under its Country House Scheme, retaining the right of the family to live in the house.

During a routine monitoring visit to the estate by the Area Archaeologist in August 2013, human bone was seen eroding from a small bedrock quarry face, located around $400 \mathrm{~m}$ to the south-west of the house (NGR: NT
04931 78446). The excavation (and subsequent analysis) of these remains was carried out by the NTS Archaeology Team, with support from the NTS Head of Conservation Services and Projects Discretionary Fund.

The landscaped parkland of the House of the Binns overlooks the River Forth to the north and the Pentland Hills to the south and contains both 17th-century garden features and earlier archaeological features, including two possible farmsteads at Scotstoun and West Craig, as noted on Roy's map ( $c$ 1750) (but which are no longer visible). A short cist, believed to be in the vicinity of the site discussed here, was found during quarrying in 1875 (Turner 1917). Turner described the feature as $c 0.9 \mathrm{~m}$ in length and made of three single upright slabs, with the fourth side of the cist being bedrock. The cist was unpaved at its base and contained at least one inhumation. An account of further discoveries of 'stone coffins' located 'near a hillock by the Black Lodge', which is located to the south-west of the house,

\footnotetext{
* This paper was awarded the RBK Stevenson Award

${ }^{1}$ National Trust for Scotland, Hermiston Quay, 5 Cultins Road, Edinburgh EH11 4DF

2 Addyman Archaeology, The Old Printworks, 77a Brunswick Street, Edinburgh EH7 5HS

${ }^{3}$ L.N.Sinfield@ed.ac.uk

4 AOC Archaeology, Edgefield Road Industrial Estate, Loanhead, Midlothian EH20 9SY

5 The Anglo-Saxon Laboratory, Bootham House, 61 Bootham, York YO30 7BT
} 


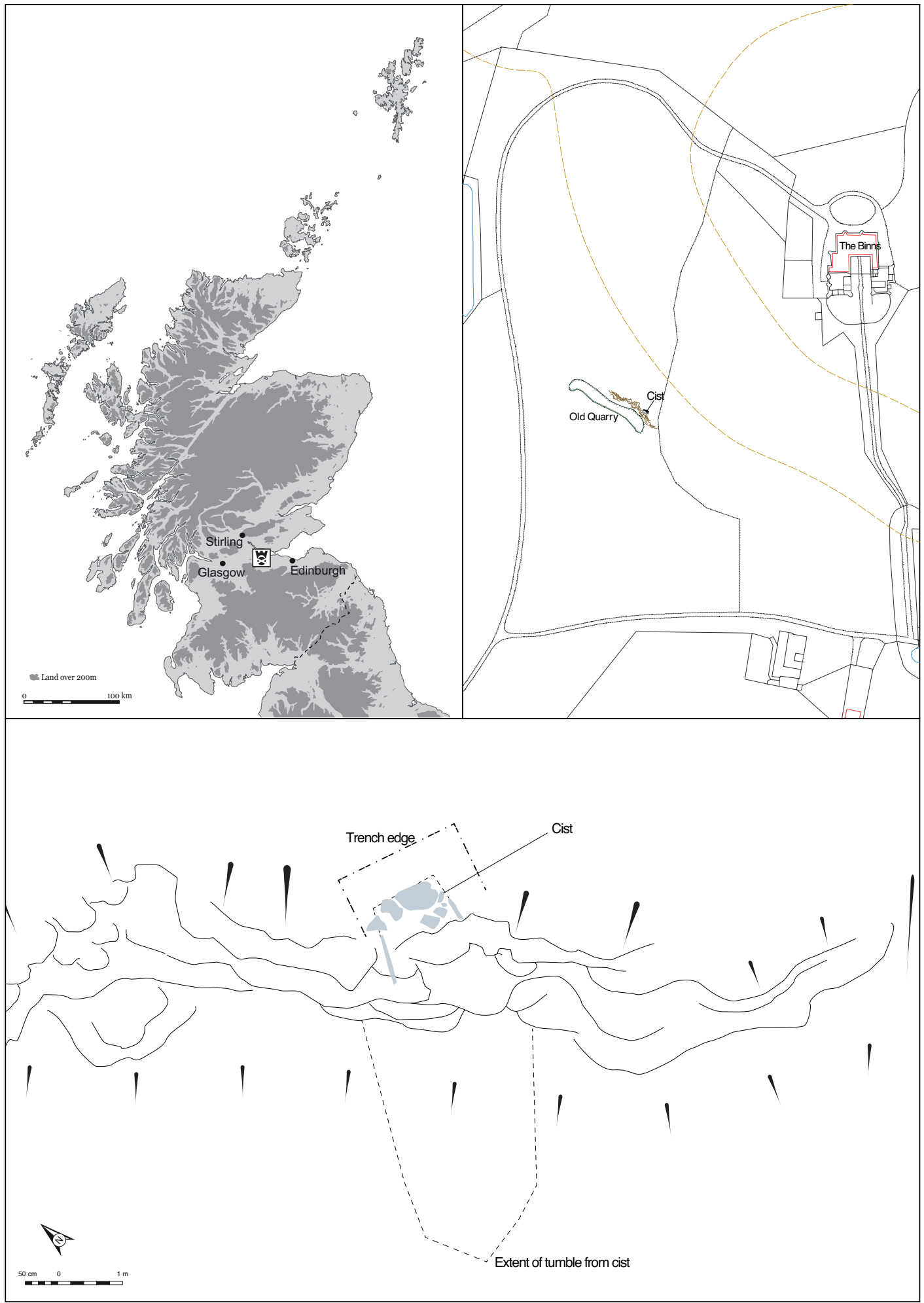

Illus 1 The House of the Binns is $5 \mathrm{~km}$ east of Linlithgow. The cist was discovered within a disused quarry in the southwest corner of the estate 
close to Binns Mill is also recorded within the archive of the National Trust for Scotland.

The site discussed in this paper was located at the south-west of the estate, adjacent to the modern driveway and at the crest of a quarried knoll at the base of the southern slope of the Binns hill (Illus 1).

\section{EXCAVATION}

The cist was formed of three upright sandstone slabs set within a vertical cut into the bedrock. The fourth side of the cist had been quarried away and the capstone had cracked in two with one half having fallen into the cist and the other having slipped down the face of the quarry some $5 \mathrm{~m}$ away (Illus 2).

A thin layer of turf overlay the collapsed capstone within the cist and upon the removal of both the cist was found to be relatively clear of any soils. The internal dimensions of the cist were $1.55 \mathrm{~m}$ east/west by $1 \mathrm{~m}$ north/south and it was approximately $0.65 \mathrm{~m}$ deep. The side slabs of the cist measured up to $0.15 \mathrm{~mm}$ thick and were closely positioned against the bedrock, with little visible soil packing between the stones and the cut. In line with the National Trust for Scotland's conservation principles, the structural integrity of the cist was assessed and judged safe to be left in situ once all the content was removed. The base of the cist was formed by the cut into bedrock and no basal slab was present. As a result the human remains present were lying directly upon the bedrock.

\section{HUMAN REMAINS}

\section{Laura Sinfield}

Upon excavation, the cist was found to contain the unburnt skeletal remains of two individuals (Illus 3 and 4). An articulated skeleton of an adult was found in a crouched position in the west of the cist interior (SK2) and an assemblage of partially disarticulated unburnt bone was present in the easternmost half of the cist (SK1). Although there were a number of bones which were not possible to assign to a specific individual as the result of post-depositional

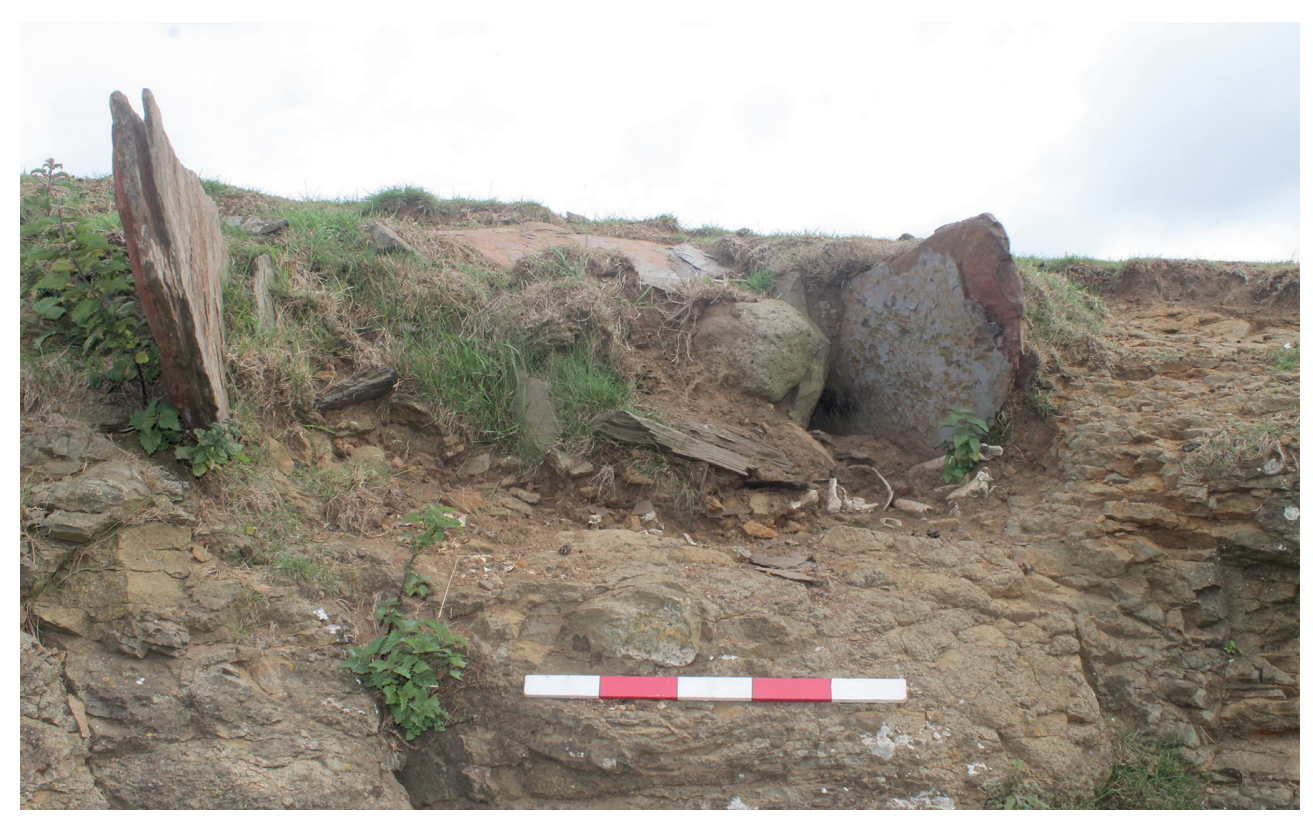

ILlus 2 On discovery the southern side and capstone of the cist had collapsed 


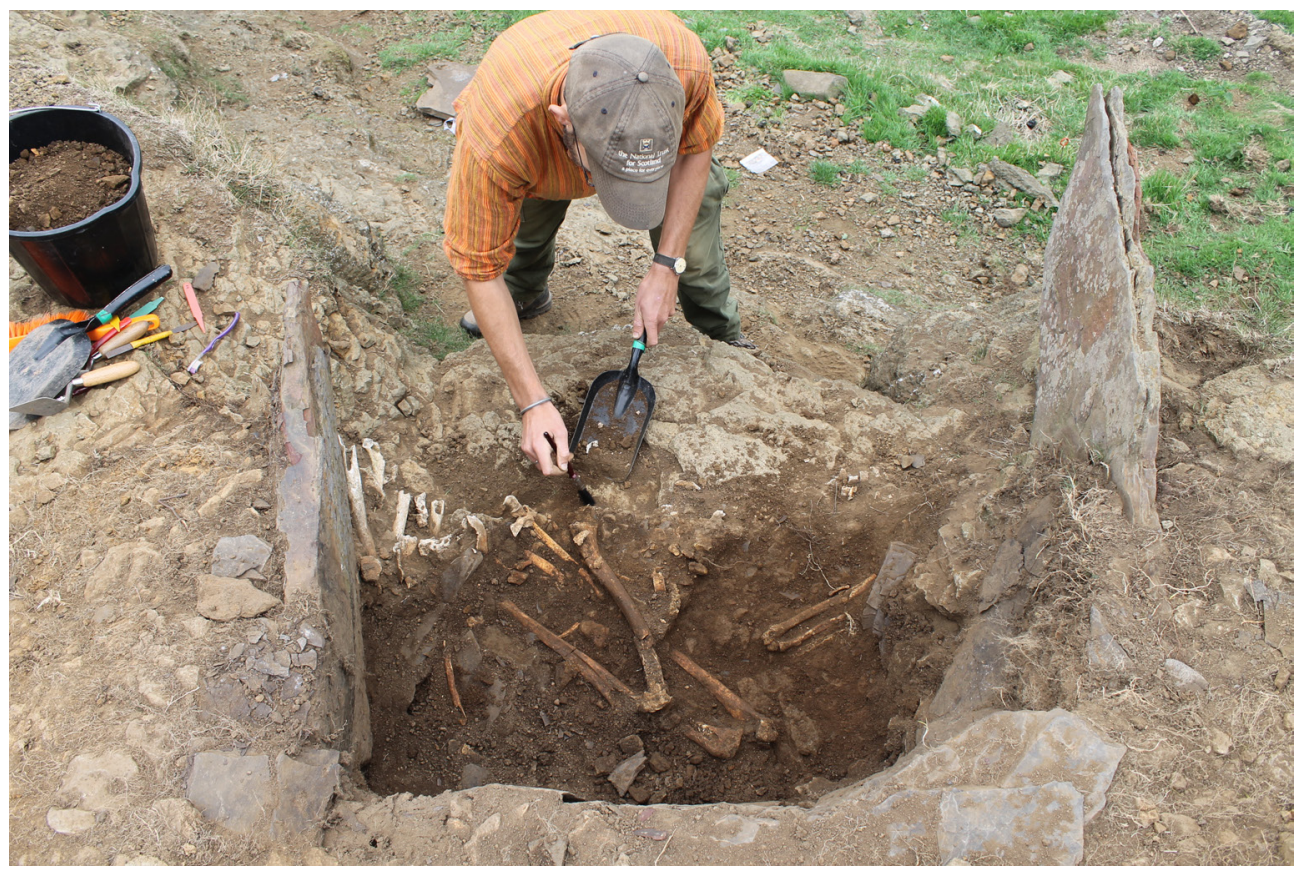

ILlus 3 The cist was excavated by the National Trust for Scotland Archaeological Service and found to contain two skeletons

disturbance (evident from the small nest within the cist and its collapse), there was no extra bone material present to suggest that more than two individuals had been interred.

SK1 was found at the inner eastern edge of the cist and comprised largely disarticulated remains. Although the bones were packed tightly together, suggesting that the body had largely decomposed prior to being moved to this position, the flexed position of the legs suggested that the skeleton was originally partially articulated, possibly in a crouched position, but was later pushed aside to enable the insertion of the second individual.

Upon analysis, SK1 was found to be a 'middle adult' male, around 30 to 50 years of age. The individual's age at death was assessed by the auricular surface of the left pelvic bones and by wear on the teeth. The sex of the individual was assessed from the shape of the surviving bones and by measurement of the humeral head. Measurement of the right arm-bones would also seem to suggest an approximate height of 166$70 \mathrm{~cm}$.
Osteological analysis also revealed signs of odontodystrophy of the canine teeth in SK1, a feature symptomatic of a series of systemic illnesses up to the age of about seven. One other abnormality was a 90 degree rotation of the lower canine teeth. The midshaft of the right tibia was radiocarbon dated to $92 \mathrm{cal} \mathrm{BC}-65$ cal $\mathrm{AD}(2 \sigma$; GU-33016, SUERC-50518).

SK2 had been laid in a crouched position on the left side with arms and legs flexed and hands at the shoulders. The head of the skeleton was at the west end of the cist, facing north. A complete iron penannular brooch was found on the left shoulder of the individual, just below the head of the humerus. On excavation, what appeared to be a layer of woven textile was attached to the brooch and pin. Two human finger-bones were also attached to the textile, suggesting the hands were placed at the left shoulder in the crouched position.

Analysis identified this individual to be a young adult male, around 15 to 25 years of age at the time of death (assessed by dental wear and the overall development of the skeleton). Sex 
was established from the shape of the surviving bones and by measurement of the femoral head. Measurement of the left leg-bones suggested a height of approximately $165-6 \mathrm{~cm}$.

Unusual striations across the outside of both upper central incisors were recognised on the teeth of SK2. These striations appear to be the result of mechanical abrasion and are quite distinct from the pitting resulting from childhood illness observed on the teeth of SK1. Evidence of mechanical abrasion of the teeth is not unknown within the archaeological record throughout the world and it has been suggested that it might indicate the holding of yarn or fibre when processing materials or weaving (Hillson 2007). However, the position of the grooves on the outer edge of the teeth in this particular case is unusual and may point at another unknown cause. The midshaft of the right femur was radiocarbon

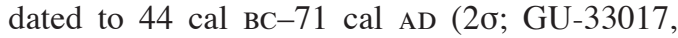
SUERC-50519).

Skeletal analysis also noted that both individuals had an unusual anomaly of the upper leg. The muscle attachment line, which normally runs directly up the back of the femur, was displaced to the outside edge, for about $20 \mathrm{~cm}$ at the top, although the lower end of this line (the linea aspera) was in the normal midline position above the knee. There is no sign of disease process in this and is therefore not thought to have caused any severe damage or disability in life. However, it is probable that both individuals may have walked with their toes turned in (pigeon-toed) as the effect of this anomaly would be to rotate the leg inwards a little.

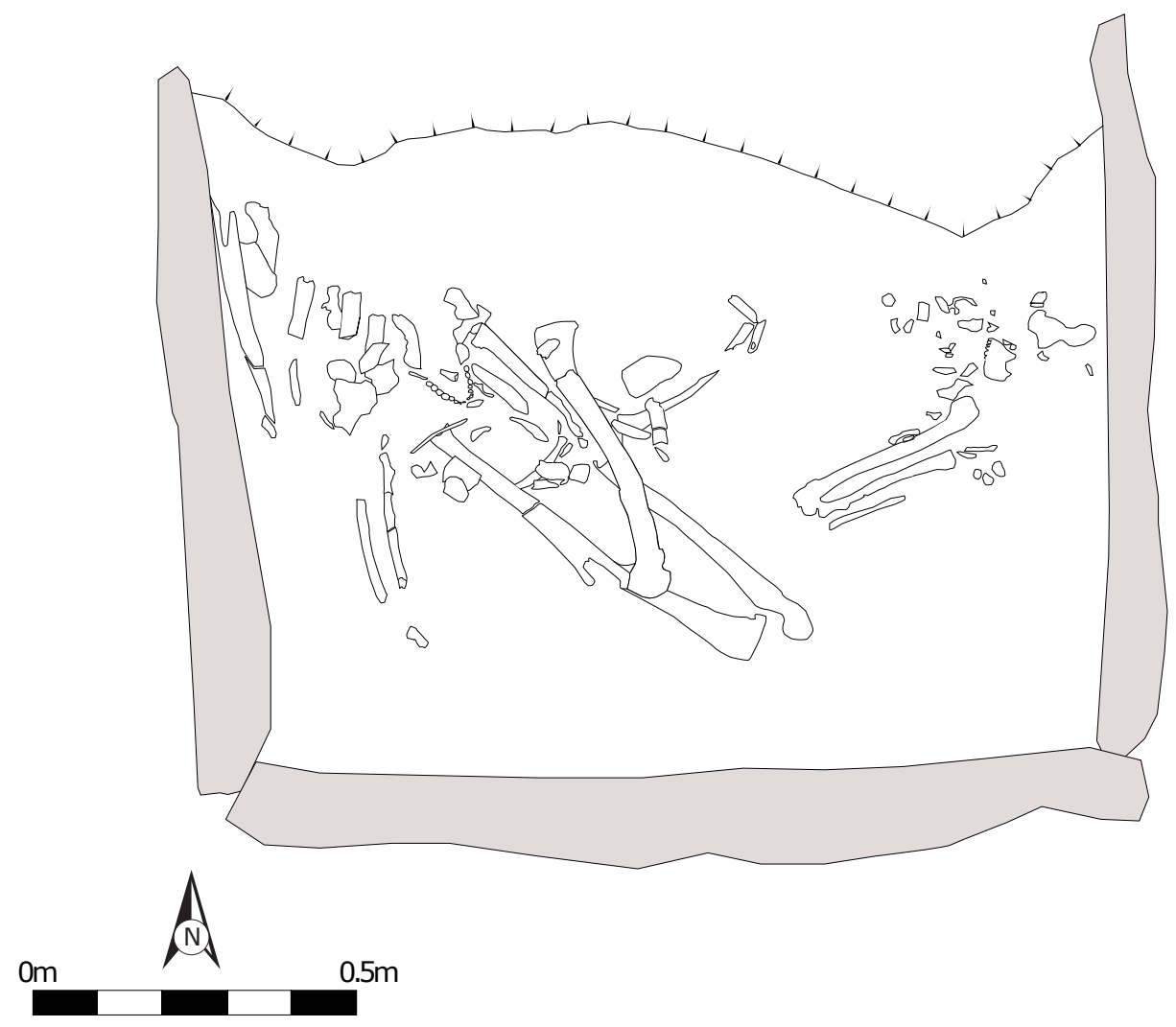

ILLus 4 Excavation clearly showed how the first burial had been displaced to the east to make way for the secondary crouched burial 


\section{THE BROOCH}

\section{Dawn McLaren}

The brooch found in association with SK2 is an intact iron penannular brooch of simple penannular form with undecorated flattened spherical terminals and intact pin (Illus 5). The penannular hoop is circular in section and very fine $(2.5 \mathrm{~mm}$ in diameter) with undecorated, bulbous terminals ( $4 \mathrm{~mm}$ in diameter). It has an external diameter of $38-42 \mathrm{~mm}$. The pin is a tapering rod or strip of iron which has been looped over the hoop to fasten and the fine tip rests on the opposing external edge of the penannular frame. The pin is $48 \mathrm{~mm}$ in length, $2.5 \mathrm{~mm}$ in width and $2 \mathrm{~mm}$ in thickness, with a gently arched profile. The hoop or frame of the brooch is slightly oval rather than strictly circular

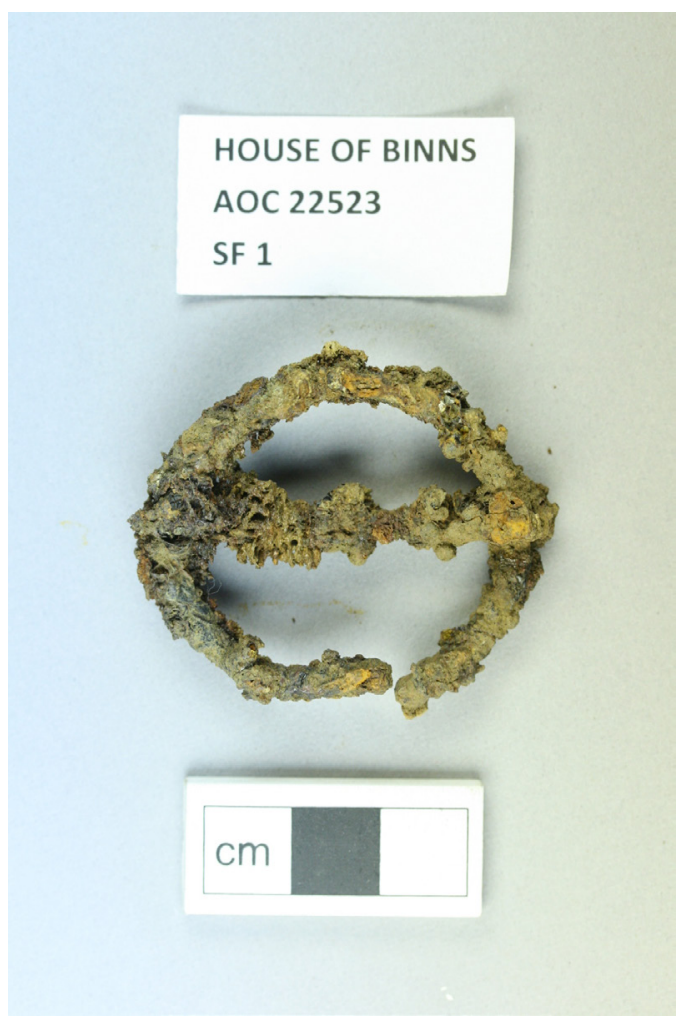

ILLUS 5 Evidence of woven cloth can clearly be seen upon the pin and hoop of the intact iron penannular brooch in plan and is slightly distorted, probably as the result of post-depositional slumping in the grave; however, this could also be damage through use prior to burial.

The form of the brooch is consistent with Fowler (1960) Type A1 and Mackreth (2011) Type K1.b brooches, defined by the small, plain, rounded knob terminals of the hoop and the slightly arched pin. Ferrous and non-ferrous penannular brooches of this form have a long currency of use, making it difficult to date the ornament precisely on form alone. Fowler suggests their use spanned the 1st century BC to 3rd century AD (Fowler 1960) whilst Mackreth's (2011) recent re-analysis notes a 2nd-century AD floruit. The direct date obtained from SK2 is of considerable value here as it places the brooch in the earlier half of Fowler's suggested date range and, significantly, emphasises the pre-Roman Iron Age use of this brooch form, contra to Mackreth's identified pattern. This is consistent with two recently excavated burials with iron penannular brooches from Musselburgh, East Lothian, which also provided pre-Roman Iron Age dates (Kirby forthcoming). Fowler refers to this type of brooch as Romano-British, suggesting they may have been imports but, like the copper alloy penannular brooch found with a child at Dunbar Golf Course, East Lothian, it is likely to be a locally produced ornament (Hunter 2002: 210).

Among the small corpus of Iron Age burials in Scotland that are associated with grave goods, dress accessories and ornaments are the commonest category and penannular brooches, of both copper alloy and iron, are the predominant type amongst the wider category of dress fasteners (Hunter 2002: 11; 2016). In general, iron penannulars are markedly less common in Scotland than copper alloy examples but differential survival in the burial context is probably a factor in this distribution.

Fewer than ten iron penannular brooches from Iron Age burials in Scotland are known. Two directly comparable examples, also of Fowler (1960) Type A1, were found in association with separate inhumation burials at Musselburgh, East Lothian (McLaren \& Hunter forthcoming). Also at this site, an unusual association of a penannular 
iron brooch with a deposit of cremated human remains was discovered. The brooch in this instance was of a different form to that from the House of the Binns example, a Fowler Type A3, and produced a 1st- to 3rd-century AD date (Kirby forthcoming).

Elsewhere, iron penannular brooches from burials are known from a cist containing at least two individuals at Law Road, North Berwick (Suddaby 2005: 55); from the burial of a young adult, possibly a female, within a cist containing two individuals at Moredun, Midlothian (Coles 1904); a cist burial at Craigie, Angus (Hutcheson 1903); with an adult male inhumation at Galson, Lewis (Neighbour et al 2000); and two examples were recovered from a cist containing multiple individuals at Lochend, Dunbar (Longworth 1966: 180-1). Although not associated with a burial, a similar penannular iron brooch is also known from The Laws, Forfar (Coles 1904: 434, fig 6).

The position of the brooch on the left shoulder of SK2 suggests that it was used to fasten a woven woollen garment, probably a cloak, at the neck or shoulder. This position is paralleled by an example found with an adult burial at Galson, Lewis (Neighbour et al 2000: 563).

A further point worth noting is that the hoop of the brooch is slightly distorted. It is not impossible that this damage has resulted from post-depositional movement within the grave but it may well be damage sustained during wear, indicating that the ornament had seen use prior to inclusion in the burial.

Despite the identification of two adult male skeletons within the cist, only one metal dress fastener was present. This may suggest a distinction in the style of costume between the two men. It is possible that the second individual wore garments that did not require a metal dress fastener or that a method of dress fastening was used that has left no archaeological trace.

\section{TEXTILE ANALYSIS}

\section{Penelope Walton Rogers}

Remains of textile preserved on the back of the hoop and the front of the pin represent a garment clasped by the penannular brooch. Iron corrosion products had completely replaced the textile and left behind a rigid facsimile of what had been a coarse tabby weave with six threads per centimetre in warp and weft. Warp and weft yarns had been spun in opposite directions $(\mathrm{Z} \times \mathrm{S})$ and both had an irregular diameter, $0.9-1.5 \mathrm{~mm}$. A tightly woven section, $10 / \mathrm{Z} \times 6 / \mathrm{S}$ threads per $\mathrm{cm}$, in the area passing over the pin, is likely to represent a selvedge (the edge of the cloth as woven on the loom). The fibres of the textile were too heavily mineralised to allow identification by ordinary optical microscopy, but the range of fibre diameters, 17-80 microns, and the general appearance of the yarn, suggested wool.

Surviving Iron Age textiles are relatively few in Scotland, but a framework has been established for Britain by the more numerous finds from East Yorkshire cemeteries (Crowfoot 1991; Bender Jørgensen 1992: 198-9; DeRoche 2012: 446-9). No chronological variation could be seen in the Yorkshire material, which stretched from the 3rd century $\mathrm{BC}$ to the 1 st century $\mathrm{AD}$. The textiles were predominantly coarse, sometimes identified as wool, with thread-counts ranging from $3 \times 4$ to $10 \times 14$ threads per $\mathrm{cm}$, and they could be woven in $2 / 2$ twill, $2 / 2$ diamond/chevron twill, or tabby, with yarn $\mathrm{Z} \times \mathrm{Z}$ or $\mathrm{Z} \times \mathrm{S}$ (ibid). Linens in tabby weave in a range of different weights have also been recorded from Late Iron Age sites in Britain (Walton Rogers 2007; 2008).

The Scottish evidence fits within this framework and two bodies from a cist burial at Dunbar provide a parallel for the House of the Binns textile (Walton Rogers 2011). Both of the Dunbar bodies were associated with coarse, probably wool, textiles with $\mathrm{Z} \times \mathrm{Z}$ spin, of uncertain weave. On one body, the textile was twisted around an iron pin from the region of the neck or shoulder; and on the other, a partially disarticulated skeleton, the textile was fastened by an iron bow brooch. There was a third textile, a finer linen, also associated with this skeleton. Finds from other Late Iron Age excavations in Scotland include a probable $2 / 2$ twill, $6 / \mathrm{Z} \times 5 /$ ? on an iron annular brooch from Craigie, near Dundee, Angus; a tabby-weave, 10/Z × 6-7/S, edged with a tablet-woven band, in association 
with ironwork from a burial at Leath Hill, Moredun, Gilmerton, Perth (Bender Jørgensen 1992: 198); and further examples are currently emerging from a warrior burial at Marshill, Alloa, Clackmannanshire. Textile fragments from later sites include finer pieces, such as the $2 / 2$ diamond twill from Balmaclellan, Kirkcudbrightshire, with $15 / Z \times 11 / \mathrm{S}$ threads per $\mathrm{cm}$ (Crowfoot 1991), although by this time some textiles may have been crossing the border from Roman Britain. Despite the paucity of the evidence, there is enough to demonstrate that in the pre-Roman Iron Age, the Scottish Lowlands had a similar textile culture to that found farther south in Britain (Bender Jørgensen 1992: 19-20; Wincott Heckett 2012: 437; DeRoche 2012: 446, 448).

Many of the coarse textiles in the Yorkshire graves were fastened at the shoulder by a single iron bow brooch and worn by adults of both sexes (Stead 1991: 80-90, 179-80). They were thought to be fasteners for the cloak, which seems a likely interpretation for several of the Scottish finds, including the one described here. If the style of the cloak was like those worn in the northern Continent at this time, it would be a large rectangle of fabric with a patterned and fringed border (Wild \& Bender Jørgensen 1988).

\section{DISCUSSION}

Iron Age burials are rare in Scotland, and ones with grave goods even rarer; only some 50 accompanied burials are known. In his list of Iron Age burials from Scotland, Colin Wallace lists only ten from eastern Scotland or Northumberland which contained multiple burials (Wallace 2011). The paucity of multiple Iron Age burials has led to suggestions that Iron Age burial traditions may have left no archaeological trace and that those graves that have been recognised may have been 'special' or even 'deviant' graves (Harding 2004: 80, 304; Dunwell \& Ralston 2008: 141).

Personal ornaments and dress accessories, such as those found here, are the most common category of accompanied burial (Hunter 2002: 211 ; 2016). The simplest form of penannular brooches, such as that discovered in the House of the Binns grave, developed in Britain about the 3rd century BC (Laing 1976: 16) and continued in use alongside other, more ornate, forms of fibula during the Roman Iron Age. In the early medieval period there was a marked revival of the popularity of the type and both simple and more ornate forms remained current until the Norse period.

The burial found at the House of the Binns fits into a small corpus of known sites, for example, those at North Belton and Lochend, near Dunbar in East Lothian. The North Belton cist also contained two male skeletons, though these were lying crouched side by side, one about 20 when he died, and the other in his late 30 s or early 40s, and was dated to the early centuries AD (Crone 1992). At Lochend, a massive cist was packed with the remains of 21 totally or partially disarticulated skeletons, with the earlier inhumations disturbed to make room for each new inhumation, demonstrating its use as a burial vault over several generations (Longworth 1966). Fragments of two penannular brooches were also discovered within the cist (Longworth 1966). Multiple burials have also been found at Camelon, Falkirk (Breeze et al 1976), and Gullane, East Lothian (Ewart \& Curle 1908).

Excavation of an Iron Age 'Warrior Grave' at Dunbar also contained two burials, with the earlier burial apparently pushed aside for the burial of the warrior (Roy 2005a; 2005b). The cist itself was similarly constructed of irregular sandstone slabs, with drystone construction on the south side and covered with three large flat sandstone slabs. The warrior lay in the bottom (western) half of the cist in a crouched position, on its left side with flexed arms and legs, with the head to the east (facing south). The earlier adult skeleton was still partially articulated when moved to make way for the secondary inhumation, suggesting the time between burials was likely to be years rather than centuries and raising the possibility they were from the same family.

The multiple cist burial at Moredun (mentioned above) contained two crouched skeletons, probably female, with heads at opposite ends of the grave (Bryce 1904; Coles 1904). A pin and a penannular brooch were associated with one skeleton and a second brooch, with fragments of a woven garment or 
wrapping adhering to it, was found in the middle of the grave. The finds give a date of late 1st-2nd century AD (Ritchie \& Ritchie 1972).

At Inveresk, East Lothian, several preRoman Iron Age burials were discovered during excavation of Roman period features (Kirby forthcoming). One inhumation burial was associated with an iron penannular brooch of similar form to that discussed here, and, like the example associated with SK2, was recovered from the left shoulder of the individual.

As well as fitting within this small body of more recent Iron Age burial evidence, at least one other burial is known on the site at the House of the Binns; a seemingly re-used short cist reported in 1917 (Turner 1917). The surviving skeletal remains were radiocarbon dated in 2006 to AD $1496 \pm 26$ (OxA-V-2166-37). However, the cist was described as being similar in construction to the recent discovery on the site described above, which might suggest that the two are part of a group of clustered burials. Again, a number of the Iron Age sites excavated in Scotland have revealed more than one burial or a small cemetery, including at Inveresk (Kirby forthcoming) and at Kirkhill, St Andrews (Rains \& Hall 1997: 7-10). While a number of the East Lothian burials appear to be of drystone construction, perhaps suggesting a regional type (Crone 1992), there are also examples of slab built cists, suggesting local resources may have played a part. One possible route of future analysis might therefore be the comparison of cist construction techniques.

As a distinct assemblage in its own right, the contents of the cist at the House of the Binns offers up some interesting opportunity for speculation. The positioning of SK1 and the conclusion that the skeleton was at least partially articulated when re-positioned to make way for SK2 suggests that it was years or perhaps (at most) decades between the burial of the two bodies. It is possible to conclude that those burying the younger man (SK2) knew of the location of the cist and the grave was probably marked in some way. The overlapping radiocarbon date ranges support the possibility that the two deceased individuals were buried in close succession. This, together with a shared upper leg anomaly, implies that they were likely to be related and, furthermore, the striations on SK1's teeth may be indicative of a craft activity such as weaving and hide preparation or other activity requiring the clamping and tension of some form of cord.

\section{REFERENCES}

Bender Jørgensen, L 1992 North European Textiles Until AD 1000. Aarhus: Aarhus University.

Breeze, D, Close-Brooks, J \& Ritchie, J N G 1976 “"Soldiers" burials at Camelon, Stirlingshire, 1922 and 1975', Britannia 7: 73-95.

Bryce, T H 1904 'Report on human remains found within a cist at Moredun, Midlothian', Proc Soc Antiq Scot 38: 439-45.

Coles, F R 1904 'Notice of the discovery of a cist of the Early Iron Age on the Estate of Moredun, near Gilmerton', Proc Soc Antiq Scot 38: 427.

Crone, B A 1992 'An Iron Age cist at North Belton Farm, Dunbar', Proc Soc Antiq Scot 122: 16170.

Crowfoot, E 1991 'The textiles', in Stead, I Iron Age Cemeteries in East Yorkshire: Excavations at Burton Fleming, Rudston, Garton-onthe-Wolds and Kirkburn (English Heritage Archaeological Report 22), 119-25. London: English Heritage.

DeRoche, D 2012, 'England: Bronze and Iron Ages', in Gleba, M \& Mannering, U (eds) Textiles and Textile Production in Europe: From Prehistory to AD 400, 444-50. Oxford: Oxbow Books.

Dunwell, A \& Ralston, I 2008 Archaeology and Early History of Angus. Stroud: Tempus.

Ewart, E \& Curle, A O 1908 'Notice of the examination of a cairn and interments of the Early Iron Age at the Black Rocks, Gullane, Haddingtonshire', Proc Soc Antiq Scot 42: 332-41.

Fowler, E 1960 'The origins and developments of the penannular brooch in Europe', Proceedings of the Prehistoric Society 26: 98-148.

Harding, D W 2004 The Iron Age in Northern Britain: Celts and Romans, Natives and Invaders. London: Routledge.

Hillson, S 2007 'Dental Pathology', in Katzenberg, M A \& Saunders, S R (eds) Biological 
Anthropology of the Human Skeleton, Second Edition, 301-40. New Jersey: John Wiley \& Sons.

Hutcheson, A 1903 'Notice of the discovery of a full-length stone cist containing human remains and a penannular brooch at Craigie, near Dundee', Proc Soc Antiq Scot 37: 233-40.

Hunter, F 2002 'The penannular brooch', in Baker, L 'An Iron Age child burial at Dunbar Golf Course, East Lothian', Proc Soc Antiq Scot 132: 211-12.

Hunter, F 2016 'Metal finds from the Iron Age burial', in Roy, M 2016 'An Iron Age warrior burial from Dunbar', Proc Soc Antiq Scot 145: 183-91.

Kirby, $\mathrm{M}$ forthcoming Excavations at Musselburgh Primary Health Care Centre: Iron Age and Roman discoveries to the north of Inveresk Roman Fort, East Lothian.

Laing, L 1976 'Penannular Brooches in Ireland and Scotland', Ulster Journal of Archaeology 39: 15-19.

Longworth, I H 1966 ‘A massive cist with multiple burials of Iron Age date at Lochend, Dunbar. Part I: the archaeological report', Proc Soc Antiq Scot 98: 173-83.

Mackreth, D F 2011 Brooches in late Iron Age and Roman Britain. Oxford: Oxbow Books.

McLaren, D \& Hunter, F 'The Iron', in Kirby forthcoming.

Neighbour, T, Knott, C, Bruce, M F \& Kerr, N W 2000 'Excavation of two burials at Galson, Isle of Lewis, 1993 and 1996', Proc Soc Antiq Scot 130: 559-84.

Rains, M J \& Hall, D W (eds) 1997 Excavations in St Andrews 1980-89: A Decade of Archaeology in a Historic Scottish Burgh. Glenrothes: TAFAC.

Ritchie, J N G \& Ritchie, A 1972 Edinburgh and South-East Scotland, Regional Archaeologies Series. London: Heinemann.

Roy, M 2005a Empire Site, Dunbar: Excavation Data Structure Report. AOC Archaeology No. 4653: unpublished archive report.
Roy, M 2005b 'Former Empire Cinema, 44 High Street, Dunbar (Dunbar parish), Late Iron age "warrior" burial; late medieval/postmedieval urban', Discovery and Excavation in Scotland 6: 51.

Stead, I 1991 Iron Age Cemeteries in East Yorkshire: Excavations at Burton Fleming, Rudston, Garton-on-the-Wolds and Kirkburn (English Heritage Archaeological Report 22). London: English Heritage.

Suddaby, I 2005 'Law Road, North Berwick', Discovery and Excavation in Scotland 6: 55.

Turner, W 1917 'A contribution to the craniology of the people of Scotland. Part II Prehistoric, descriptive and ethnographical', Transactions of the Royal Society of Edinburgh 51: 190.

Wallace, C R 2011 'A rough handlist of Iron Age and Roman Iron Age burials from Scotland C8BC - C5AD'. https://www.academia. edu/1743090/handlist_of_Iron_Age_burials_ from_Scotland 2003, revised 2011. Accessed 10 December 2014.

Walton Rogers, P 2007 'Textile remains', in Sealey, P R 'A Late Iron Age Warrior Burial from Kelvedon, Essex', East Anglian Archaeology 118: 26. Colchester: Colchester Museums.

Walton Rogers, P 2008 'Textiles', in Booth, P, Bingham, A-M \& Lawrence, S The Roman Roadside Settlement at Westhawk Farm, Ashford, Kent, Excavations 1998-9, 305-6. Oxford: Oxford Archaeological Unit.

Walton Rogers, P 2011 Textiles from the Iron Age cist grave, 1022, at Dunbar (Empire), project 4653, on behalf of Fraser Hunter, National Museums Scotland. ASLab Report No. 110907, unpublished archive report.

Wild, J P \& Bender Jørgensen, L 1988 'Clothes from the Roman Empire - barbarians and Romans', in Bender Jørgensen, L \& Tidow, K (eds), Archaeological Textiles (NESAT II). Copenhagen: University of Copenhagen.

Wincott Heckett, E 2012 'Scotland and Ireland', in Gleba, M \& Mannering, U (eds) Textiles and Textile Production in Europe: From Prehistory to $A D$ 400, 428-42. Oxford: Oxbow Books.

This paper is published with the aid of a grant from the National Trust for Scotland 